DOI: $10.19195 / 0137-1134.111 .9$

\author{
KARINA PILARZ
}

Uniwersytet Wrocławski

\title{
SPECYFIKA RELACJI ORGANÓW ADMINISTRACJI PUBLICZNEJ Z OTOCZENIEM W SYTUACJACH KRYZYSOWYCH
}

\begin{abstract}
Abstrakt: Z sytuacją kryzysową mamy do czynienia w wypadku poważnego zagrożenia bezpieczeństwa, wymagającego podjęcia szczególnych kroków, niedającego jednak podstaw do wprowadzenia jednego z konstytucyjnych stanów nadzwyczajnych. Ustawa o zarządzaniu kryzysowym określa katalog zadań, jakie w sytuacji takiej spoczywają na organach samorządu terytorialnego (gminy oraz powiatu) oraz organach administracji państwowej. Zintegrowany system zarządzania kryzysowego składa się z organów zarządzania kryzysowego, organów pomocniczych oraz centrów zarządzania kryzysowego. W sytuacjach kryzysowych organy administracji publicznej mogą również współdziałać z otoczeniem. W opracowaniu poddano analizie sytuacje, w których administracja wspierana jest zasobami osobowymi, sprzętowymi, a także informacyjnymi przez Siły Zbrojne RP oraz organizacje pozarządowe, we wszystkich fazach zarządzania kryzysowego.
\end{abstract}

Słowa kluczowe: sytuacja kryzysowa, zarządzanie kryzysowe

\section{WPROWADZENIE}

Słownik terminów z zakresu bezpieczeństwa narodowego definiuje sytuację kryzysową jako stan narastającej destabilizacji, niepewności i napięcia społecznego, zagrażający w szczególności integralności terytorialnej, życiu, zdrowiu, mieniu, dziedzictwu kulturowemu, środowisku lub infrastrukturze krytycznej, w tym spowodowany zdarzeniem o charakterze terrorystycznym, charakteryzujący się możliwością utraty kontroli nad przebiegiem wydarzeń albo eskalacji zagrożenia ${ }^{1}$.

Definicję legalną tego pojęcia prawodawca umieścił natomiast $\mathrm{w}$ ustawie o zarządzaniu kryzysowym. Oznacza ona taką sytuację, która negatywnie wpływa na bezpieczeństwo ludności, środowiska lub mienia w znacznych rozmiarach lub też jest przyczyną znacznych ograniczeń w działalności organów administra-

1 Akademia Obrony Narodowej, Stownik terminów z zakresu bezpieczeństwa narodowego, Warszawa 2008. 
cji publicznej. Przyczyną ograniczeń jest nieadekwatność sił i środków, jakimi administracja dysponuje ${ }^{2}$. Z definicji wynika, że z sytuacją kryzysową mamy do czynienia w efekcie poważnego zagrożenia, które może być zarówno abstrakcyjne, jak i konkretne. Zagrożenie to oddziałuje negatywnie na bezpieczeństwo oraz dotyczy nieograniczonej liczby ludzi, jest więc powszechne. Ustawodawca, definiując sytuację kryzysową, nie uwzględnia zatem zagrożeń, które są indywidualne, dotyczą przypadków jednostkowych. Negatywne oddziaływanie może być zarówno bezpośrednie (gdy dotyczy zdrowia i życia ludzi), jak i pośrednie (jeśli odnosi się do mienia oraz środowiska). Wątpliwości mogą jednak budzić użyte przez prawodawcę pojęcia niemierzalne, nie wiemy bowiem, z iloma poszkodowanymi bądź z jakiej wysokości stratami musimy mieć do czynienia, by można było daną sytuację zakwalifikować jako kryzysową. Problem ten rozstrzygany jest przy użyciu kryteriów subiektywnych, sytuacja kryzysowa zaistnieje zatem po przekroczeniu pewnej granicy akceptowanego stanu bezpieczeństwa, która nie dla każdego przebiega w tym samym miejscu. Niejednoznaczne może być również określenie, kiedy mamy do czynienia ze znacznym ograniczeniem w działaniu organów administracyjnych. Zawsze jednak wynikać musi ono z nieadekwatności sił i środków będących w dyspozycji administracji. Może to być niedostatek zasobów ludzkich, materialnych oraz sposobów, które zapewniłyby skuteczne działanie organów ${ }^{3}$.

W definicji sytuacji kryzysowej prawodawca nie zawarł zamkniętego katalogu przyczyn, które mogą ją spowodować. Nie ma bowiem takiej możliwości, by wskazać wszystkie zagrożenia, jakie mogą zaistnieć i jakim będzie musiała przeciwdziałać administracja publiczna. Ustawodawca ograniczył się zatem do wskazania tylko ogólnie wspólnych cech przyczyn sytuacji kryzysowej, natomiast obowiązek ich ukonkretnienia spoczywa na ustawach ustrojowych odnoszących się do funkcjonowania konkretnych organów ${ }^{4}$.

Obowiązek ustalenia, czy mamy już do czynienia z sytuacją kryzysową, spoczywa przede wszystkim na organach administracji publicznej. Można uznać, że sytuacja kryzysowa jest to stan przejściowy między zagrożeniami codziennymi a zagrożeniami szczególnymi. Zagrożenia codzienne charakteryzują się przede wszystkim wysoką częstotliwością występowania, a także ograniczonymi skutkami (jeśli chodzi o liczbę ofiar czy wysokość strat materialnych). Ich zwalczanie nie będzie wymagało żadnego nadzwyczajnego postępowania, angażowania dodatkowych sił ani zwiększania uprawnień. Zagrożenia szczególne natomiast występują bardzo rzadko, ale niosą poważne konsekwencje. Sytuację kryzysową możemy przedstawić jako wykraczającą poza zagrożenia codzienne, wymaga ona bowiem

2 Zob. art. 3 ust. 1 ustawy z dnia 26 kwietnia 2007 roku o zarządzaniu kryzysowym (Dz.U. z 2017 r. poz. 209).

3 M. Brzeziński, Sytuacja kryzysowa w rozumieniu ustawy z dnia 26 kwietnia 2007 r. o zarzadzaniu kryzysowym - analiza pojęcia, „e-Politikon” 2013, nr 6, s. 85-87.

4 Ibidem, s. 87. 
podjęcia pewnych działań szczególnych. Mieści się ona jednak w granicach normalnego funkcjonowania państwa, ponieważ nie daje podstaw do wprowadzenia jednego z konstytucyjnych stanów nadzwyczajnych ${ }^{5}$. W pierwotnej wersji ustawy definicja sytuacji kryzysowej wskazywała wprost, że środki użyte do zapewnienia lub przywrócenia bezpieczeństwa nie są uzasadnieniem wprowadzenia żadnego ze stanów nadzwyczajnych ${ }^{6}$. Za kres sytuacji kryzysowej możemy uznać moment, w którym powraca się do stanu sprzed jej wystąpienia bądź zmienia się w sytuację szczególną, będącą podstawą do wprowadzenia ograniczeń wynikających ze stanów nadzwyczajnych ${ }^{7}$.

Kolejnym istotnym pojęciem związanym z analizowaną materią jest ,zarządzanie kryzysowe". Terminem tym określa się całokształt działań organów, które mają na celu zapobieganie wystąpieniu sytuacji kryzysowej oraz odpowiednie reagowanie w wypadku jej zaistnienia i usuwanie ewentualnych skutków. Stanowi ono, zgodnie z postanowieniami ustawodawcy, element kierowania bezpieczeństwem narodowym ${ }^{8}$.

System zarządzania kryzysowego oparty jest na zasadniczym podziale terytorialnym Rzeczypospolitej, w związku z czym struktury wchodzące w jego skład funkcjonują na poziomie gminy, powiatu oraz województwa. W doktrynie odnaleźć można wiele definicji zarządzania kryzysowego, wspólną cechą zawsze jest traktowanie go jako procesu - wyróżnia się w nim poszczególne cykle oraz jego zamknięty charakter, bezpośrednio po ustaniu danej sytuacji kryzysowej rozpoczyna się bowiem faza przygotowania do następnej. Wskazuje się na cztery podstawowe fazy procesu zarządzania kryzysowego: zapobiegania, przygotowania, reagowania oraz odbudowy. Dwie pierwsze zbiorczo określić można fazą planowania, a dwie kolejne fazą realizacji.

Jak już wspomniano, zarządzanie kryzysowe stanowi integralną część bezpieczeństwa narodowego. Nie ma jednak wyraźnie określonych granic, które oddzielałyby od siebie te dwa obszary, albowiem przenikają się one wzajemnie. System bezpieczeństwa narodowego wspiera system zarządzania kryzysowego w sytuacjach kryzysowych, na przykład w momencie opisanego w kolejnej części pracy wykorzystania oddziałów lub pododdziałów Sił Zbrojnych RP9 9

${ }^{5}$ Konstytucja Rzeczypospolitej Polskiej z dnia 2 kwietnia 1997 roku (Dz.U. Nr 78, poz. 483 z późn. zm.) w art. 128 przewiduje możliwość wprowadzenia w sytuacjach szczególnych zagrożeń stanu wojennego, stanu wyjątkowego lub stanu klęski żywiołowej.

${ }^{6}$ Por. art. 3 pkt 1 ustawy z dnia 26 kwietnia 2007 roku o zarządzaniu kryzysowym (Dz.U. $\mathrm{Nr} 89$, poz. 590).

7 M. Brzeziński, op. cit., s. 88-96.

8 Zob. art. 2 ustawy z dnia 26 kwietnia 2007 roku o zarządzaniu kryzysowym.

9 J. Falecki, Dylematy zarządzania kryzysowego w Rzeczypospolitej Polskiej, Sosnowiec 2016, s. 109. 


\section{ZADANIA ORGANÓW ADMINISTRACJI PUBLICZNEJ W SYTUACJI KRYZYSOWEJ}

\section{USTALENIA WSTĘPNE}

W ustawie o zarządzaniu kryzysowym wskazane zostały przez prawodawcę organy właściwe sprawom zarządzania kryzysowego. Wskazane zostały również ich zadania i obowiązki. Wspólnie tworzą one wieloszczeblowy system, który składa się z: organów zarządzania kryzysowego, organów pomocniczych oraz centrów zarządzania kryzysowego. System ten jest zintegrowany, kompleksowo wiąże poszczególne komponenty w funkcjonalną całość ${ }^{10}$.

\section{ZADANIA ADMINISTRACJI SAMORZĄDOWEJ}

Jednostkami samorządu terytorialnego, które uczestniczą w zarządzaniu kryzysowym, są gmina oraz powiat. Zgodnie z postanowieniami Konstytucji RP podstawową jednostką samorządu jest gmina ${ }^{11}$. Organem właściwym na jej terenie w sprawach zarządzania kryzysowego jest organ wykonawczy, to znaczy wójt, burmistrz lub prezydent miasta. Oznacza to, że zgodnie z zamiarem ustawodawcy w ramach zarządzania kryzysowego mamy w gminie do czynienia z zarządzaniem jednoosobowym. Skutkuje to także jednoosobową odpowiedzialnością za podjęte decyzje $^{12}$. Do zadań organu wykonawczego gminy w tym zakresie należy: kierownictwo nad monitorowaniem, planowaniem, reagowaniem oraz usuwaniem skutków zaistniałych zagrożeń, realizowanie zadań związanych z planowaniem cywilnym ${ }^{13}$, prowadzenie szkoleń z dziedziny zarządzania kryzysowego, zapobieganie i przeciwdziałanie zdarzeniom mającym charakter terrorystyczny oraz usuwanie ich skutków. Przydzielone przez ustawodawcę zadania wójt wykonuje z pomocą właściwej w sprawach zarządzania kryzysowego komórki organizacyjnej gminy. Na terenie gminy działa też gminny zespół zarządzania kryzysowego, którego zadaniem jest pomoc organowi wykonawczemu przy zapewnieniu wykonania określonych ustawą zadań ${ }^{14}$. Pracami zespołu kieruje wójt, który powołuje go w sposób samodzielny oraz określa jego skład, organizację, siedzibę oraz tryb

10 W. Walczak, Zarzadzanie kryzysowe - rola i zadania organów administracji państwowej, „Przedsiębiorczość i Zarządzanie” 10, 2009, z. 8, s. 98-101.

11 Zob. art. 164 ust. 1 Konstytucji Rzeczypospolitej Polskiej.

12 A. Ostapski, Zadania gminy w zakresie bezpieczeństwa, [w:] Bezpieczeństwo wewnętrzne $w$ działaniach terenowej administracji publicznej, red. A. Chajbowicz, T. Kocowski, Wrocław 2009, s. 173.

13 Zgodnie z art. 3 pkt 4 ustawy o zarządzaniu kryzysowym planowanie cywilne to całokształt przedsięwzięć organizacyjnych, które mają na celu przygotowanie administracji do zarządzania kryzysowego oraz planowanie wspierania Sił Zbrojnych RP w przypadku ich użycia oraz planowanie ich wykorzystania do realizacji zadań z zakresu zarządzania kryzysowego.

14 Zob. art. 19 i art. 20 ustawy o zarządzaniu kryzysowym. 
pracy ${ }^{15}$. Zadaniem wójta jest również zapewnienie realizacji określonych przez prawodawcę zadań takich, jak: alarmowanie przez całą dobę członków zespołu gminnego, zapewnienie całodobowego dyżuru w sytuacjach kryzysowych, współpraca $\mathrm{z}$ centrami zarządzania kryzysowego innych organów administracyjnych oraz współdziałanie z podmiotami, które prowadzą akcje ratownicze, poszukiwawcze czy humanitarne. Celem realizacji tych zadań utworzone może zostać gminne (miejskie) centrum zarządzania kryzysowego) ${ }^{16}$.

Analogiczne kompetencje przysługują staroście, który jako przedstawiciel organu wykonawczego, czyli zarządu powiatu, jest na obszarze powiatu organem właściwym w sprawach związanych z zarządzaniem kryzysowym. Swoje ustawowe zadania wykonuje on za pomocą jednostek organizacyjnych powiatu oraz powiatowej administracji zespolonej. Powołuje również powiatowy zespół zarządzania kryzysowego oraz określa jego skład, organizację, siedzibę i tryb pracy. Za przepływ informacji na potrzeby zarządzania kryzysowego odpowiadają natomiast powiatowe centra zarządzania kryzysowego, które wykonują zadania tożsame $\mathrm{z}$ zadaniami centrum na terenie gminy ${ }^{17}$.

\section{ZADANIA ADMINISTRACJI RZĄDOWEJ}

Zarządzanie kryzysowe na terytorium RP sprawowane jest przez Radę Ministrów, jednak w przypadkach niecierpiących zwłoki obowiązek ten spada na ministra właściwego do spraw wewnętrznych. O swoich działaniach musi on jednak niezwłocznie powiadomić Prezesa Rady Ministrów. Do zadań Rady Ministrów w zakresie zarządzania kryzysowego należy przyjęcie w drodze uchwały raportu o zagrożeniach bezpieczeństwa narodowego, który sporządzany jest przez ministrów kierujących działami administracji rządowej, kierowników urzędów centralnych oraz wojewodów. Raport zawiera mapę ryzyka, która wskazuje najważniejsze zagrożenia, określa cele strategiczne, a także priorytety reagowania na zagrożenia. Uwzględniając regionalne i lokalne inicjatywy, raport programuje zadania mające na celu poprawę bezpieczeństwa oraz przedstawia wnioski, które wskazują na przedsięwzięcia konieczne do osiągnięcia strategicznych celów. Kolejnym aktem, jaki Rada Ministrów przyjmuje w drodze uchwały, jest Narodowy Program Ochrony Infrastruktury Krytycznej. Ma on na celu stworzenie takich warunków, które pozwolą na zapobieganie zakłóceniom w funkcjonowaniu infrastruktury, odpowiednie przygotowanie się, reagowanie w sytuacjach negatywnych funkcjonowania infrastruktury krytycznej oraz jej ewentualne odtwarzanie ${ }^{18}$.

15 T.Z. Leszczyński, Kluczowe zadania administracji samorzadowej w zarządzaniu kryzysowym. Bezpieczeństwo i zarządzanie kryzysowe, „Przedsiębiorczość i Zarządzanie” 10, 2009, s. 74.

16 Art. 20 ustawy o zarządzaniu kryzysowym.

17 Art. 17 i art. 18 ustawy o zarządzaniu kryzysowym.

18 Zob. art. 7, art. 5a oraz art. 56 ustawy o zarządzaniu kryzysowym. 
Organem opiniodawczo-doradczym Rady Ministrów jest Rządowy Zespół Zarządzania Kryzysowego. Jest on właściwy w sprawach inicjowania oraz koordynowania wszelkich działań, które podejmowane są w zakresie zarządzania kryzysowego. W jego skład wchodzą takie organy, jak: Prezes Rady Ministrów jako przewodniczący, Minister Obrony Narodowej i minister właściwy do spraw wewnętrznych jako zastępcy przewodniczącego, Minister Spraw Zagranicznych oraz Minister Koordynator Służb Specjalnych (jeśli został powołany). Do zadań zespołu należy opiniowanie Krajowego Planu Zarządzania Kryzysowego, doradztwo w sprawach koordynacji działań podejmowanych w sytuacjach kryzysowych przez organy administracji rządowej, instytucje państwowe i służby oraz propozycje dotyczące użycia sił i środków, które konieczne są do opanowania sytuacji kryzysowej ${ }^{19}$.

W krajowym systemie zarządzania kryzysowego funkcjonuje również Rządowe Centrum Bezpieczeństwa. Jest ono państwową jednostką budżetową. Podlega Prezesowi Rady Ministrów, który powołuje i odwołuje kierującego nim dyrektora. Utworzenie Rządowego Centrum Bezpieczeństwa miało na celu rozpoczęcie budowy takiego systemu zarządzania kryzysowego, który będzie efektywny oraz kompletny. Jego zadaniem jest zapobieganie kryzysom, a także podejmowanie profesjonalnych działań i zminimalizowanie negatywnych konsekwencji, jeżeli kryzys zaistnieje. Struktura systemu jest ponadresortowa, a jej celem jest zwiększenie umiejętności radzenia sobie w trudnych sytuacjach, zarówno przez odpowiednie służby, jak i przez organy administracji publicznej ${ }^{20}$. Centrum zapewnia wsparcie niezbędne przy podejmowaniu decyzji dotyczących kwestii bezpieczeństwa, dostarcza opracowania i analizy zagrożeń, które tworzy na podstawie danych otrzymanych z innych ośrodków kryzysowych oraz od partnerów międzynarodowych. Centrum odgrywa zatem rolę kluczową w procesie przepływu informacji o zagrożeniach ${ }^{21}$. Szczegółowe informacje dotyczące funkcjonowania Centrum, jego struktury, a także zadania i kompetencje dyrektora, określone zostały w rozporządzeniu Prezesa Rady Ministrów 22 .

Zadania z zakresu zarządzania kryzysowego realizowane są również przez ministrów kierujących działami administracji rządowej oraz kierowników urzędów centralnych. Opracowują oni plany zarządzania kryzysowego, które zawierają między innymi analizę możliwego wystąpienia zagrożeń, sposoby reakcji na zagrożenia oraz likwidowania ich skutków czy też organizację realizacji zadań odnoszących się do ochrony infrastruktury krytycznej. Na potrzeby zrealizowania ustawowych zadań ministrowie oraz kierownicy tworzą zespoły zarządzania

19 Zob. art. 8 i art. 9 ustawy o zarządzaniu kryzysowym.

20 Serwis internetowy Rządowego Centrum Bezpieczeństwa, http://rcb.gov.pl/o-rcb/ (dostęp: 24.03.2017).

21 W. Walczak, op. cit., s. 99-100.

22 Rozporządzenie Prezesa Rady Ministrów z dnia 11 kwietnia 2011 roku w sprawie organizacji i trybu działania Rządowego Centrum Bezpieczeństwa (Dz.U. z 2015 r. poz. 508). 
kryzysowego, których organizację, skład i tryb pracy określają w formie zarządzenia. Ministrowie oraz centralne organy administracji rządowej tworzą centra zarządzania kryzysowego. Ich zadania są tożsame z centrami gminnymi oraz powiatowymi ${ }^{23}$.

Na obszarze województwa organem odpowiedzialnym za zarządzanie kryzysowe jest wojewoda, który zgodnie z przepisem ustawy o wojewodzie i administracji rządowej w województwie jest organem rządowej administracji zespolonej w województwie ${ }^{24}$. Wypełnia on zadania podobne do zadań wójta $\mathrm{w}$ gminie i starosty w powiecie. Swoje zadania wojewoda wykonuje, współpracując z właściwymi organami administracyjnymi, natomiast jego organem pomocniczym jest wojewódzki zespół zarządzania kryzysowego, który sam powołuje. W ramach województwa funkcjonują centra zarządzania kryzysowego, których zadania są takie same jak centrum gminnego i powiatowego ${ }^{25}$.

\section{WSPÓŁDZIAŁANIE Z OTOCZENIEM}

\section{POJĘCIE WSPÓŁDZIAŁANIA}

Słownik języka polskiego definiuje współdziałanie jako działanie wspólnie z kimś, przyczynianie się do czegoś wraz z innymi czynnikami oraz funkcjonowanie $\mathrm{w}$ powiązaniu $\mathrm{z}$ innymi ${ }^{26}$.

Współdziałanie władz publicznych wymienione zostało w preambule Konstytucji RP wśród zasad, na których oparte są podstawowe prawa państwa. Nie ma zatem wątpliwości, że organy administracyjne nie są od siebie bezwzględnie rozdzielone i nie wykonują wszystkich swoich zadań i kompetencji całkowicie samodzielnie. Wręcz przeciwnie, w niektórych sytuacjach konieczne jest wykonywanie powierzonych danemu organowi zadań we współdziałaniu z innym podmiotem. Współdziałanie, mające ułatwiać realizowanie przewidzianych prawem zadań, może być podejmowane zarówno wewnątrz struktury administracji samorządowej, jaki i między jednostkami samorządu terytorialnego a administracją rządową. Organy administracji publicznej mogą też podejmować współpracę z otoczeniem, jak w wypadku wskazanej dalej współpracy administracji z siłami zbrojnymi RP oraz organizacjami pozarządowymi w sytuacjach kryzysowych.

Wśród przyczyn podejmowania przez organy administracji publicznej różnego rodzaju form współdziałania doktryna wskazuje na potrzebę zapewnienia wsparcia merytorycznego przy rozstrzyganiu spraw, które wymagają specjali-

${ }^{23}$ Zob. art. 12 i art. 13 ustawy o zarządzaniu kryzysowym.

${ }^{24}$ Por. art. 3 ust. 1 pkt 3 ustawy z dnia 23 stycznia 2009 roku o wojewodzie i administracji rządowej w województwie (Dz.U. z 2015 r. poz. 525 z późn. zm.).

25 Zob. art. 14 ustawy o zarządzaniu kryzysowym.

26 https://sjp.pwn.pl/szukaj/wsp\%C3\%B3\%C5\%82dzia\%C5\%82anie.html. 
stycznej wiedzy, a także na rozszerzanie zasięgu działania terenowych organów administracyjnych, zapewnienie możliwości wzajemnej kontroli przez organy administracji publicznej, łagodzenie podziałów kompetencyjnych oraz włączanie w działania administracji rządowej samorządu terytorialnego ${ }^{27}$.

Przepisy prawa powszechnie obowiązującego zawierają katalogi zadań i kompetencji przewidzianych dla poszczególnych jednostek samorządu terytorialnego. Jednocześnie jednak przepisy ustaw ustrojowych (o samorządzie gminnym, o samorządzie powiatowym oraz o samorządzie województwa) dają tym jednostkom prawną możliwość realizowania tych zadań i kompetencji we współdziałaniu. Współdziałanie to odbywa się głównie w układzie poziomym (na przykład związki i porozumienia międzygminne, stowarzyszenia gmin, związki, porozumienia i stowarzyszenia powiatów), ale możliwe jest tworzenie związków powiatowo-gminnych ${ }^{28}$. Związki te mają na celu wspólne wykonywania zadań publicznych, w tym także wydawanie decyzji w sprawach indywidualnych z zakresu administracji publicznej ${ }^{29}$.

Oprócz możliwych form współdziałania wewnątrz sektora samorządu terytorialnego przepisy ustaw ustrojowych przewidują współdziałanie między organami administracji rządowej a jednostkami samorządu terytorialnego. Do form tego współdziałania możemy zaliczyć konstytucyjną konstrukcję, w drodze ustawy, zlecania jednostkom samorządu terytorialnego zadań z zakresu administracji rządowej oraz dobrowolnie zawierane porozumienia. Jak wskazuje J. Korczak, porozumienia te nie wywierają wpływu na ustrojowe relacje zachodzące pomiędzy organem powierzającym i organem wykonującym powierzone zadania. Jednak w wypadku zadań z zakresu administracji rządowej wykonywanych przez jednostki samorządu terytorialnego, poza zwyczajowym nadzorem sprawowanym przez wojewodę, mamy dodatkowo do czynienia z wykonywaną przez niego kontrolą ${ }^{30}$. Odbywa się ona na podstawie art. 3 ust. 2 ustawy o wojewodzie i administracji rządowej w województwie, zgodnie z którym „Wojewoda kontroluje pod względem legalności, gospodarności i rzetelności wykonywanie przez organy samorządu terytorialnego zadań z zakresu administracji rządowej, realizowanych przez nie na podstawie ustawy lub porozumienia z organami administracji rządowej"31. Jak już wspomniano, organy administracji publicznej mogą część swoich zadań wykonywać nie tylko we współdziałaniu z innymi organami, lecz także z oto-

27 Prawo administracyjne, red. M. Wierzbowski, Warszawa 2017, s. 83-85.

28 Prawo administracyjne. Pojęcia, instytucje, zasady w teorii i orzecznictwie, red. M. Stahl, Warszawa 2016, s. 439-445.

29 Art. 72a ust. 1 ustawy z dnia 5 czerwca 1998 roku o samorządzie powiatowym (Dz.U. z 2016 r. poz. 814 z późn. zm.).

30 J. Korczak, Współdziałanie organów administracji rządowej i samorzadowej $w$ stanach nadzwyczajnych, [w:] Powszechna ochrona ludności w stanach nadzwyczajnych $w$ zadaniach terenowej administracji publicznej, red. M. Błażewski, T. Kocowski, M. Raduła, Wrocław 2016, s. $85-86$.

31 Art. 3 ust. 2 ustawy z dnia 23 stycznia 2009 roku o wojewodzie i administracji rządowej w województwie (Dz.U. z 2015 r. poz. 525 z późn. zm.). 
czeniem. W sytuacji kryzysowej współdziałanie takie będzie konieczne, jeśli administracja nie dysponuje odpowiednim zasobem środków (zarówno osobowych, jak i sprzętowych). Wówczas do uporania się z zaistniałą sytuacją administracja korzysta ze wsparcia spoza struktury administracyjnej. W niniejszym opracowaniu za przykład relacji między organami administracyjnymi a otoczeniem posłuży współpraca z siłami zbrojnymi RP oraz z organizacjami pozarządowymi.

\section{WSPÓŁDZIAŁANIE Z SIŁAMI ZBROJNYMI RP}

Zadaniem sił zbrojnych RP jest służenie w celu ochrony niepodległości państwa oraz niepodzielności jego terytorium. Mają one zapewniać bezpieczeństwo i nienaruszalność jego granic. Stanowią główny składnik systemu obronnego państwa, w związku z tym uczestniczą w realizacji polityki bezpieczeństwa oraz polityki obronnej. Do zadań sił zbrojnych należy między innymi obrona państwa, uczestnictwo z operacjach obronnych w kraju i poza nim, a także udział w stabilizowaniu sytuacji na arenie międzynarodowej oraz w operacjach humanitarnych. Obowiązkiem jest również wspieranie bezpieczeństwa wewnętrznego oraz pomoc społeczeństwu i to w tej kategorii zadań mieścić się będzie ich współpraca z organami administracji publicznej w zakresie zarządzania kryzysowego ${ }^{32}$. Siły zbrojne wspierają administrację w sytuacjach kryzysowych potencjałem zarówno osobowym, jak i sprzętowym. W zależności od potrzeby współpracują z jednostkami administracyjnymi, służbami oraz inspekcjami, na różnych szczeblach administracyjnych ${ }^{33}$.

Siły zbrojne pełnią funkcję pomocniczą oraz wspierającą struktury cywilne, gdy możliwości innych sił się wyczerpią. Podstawowym aktem prawnym dotyczącym zarządzania kryzysowego, a więc również użycia sił zbrojnych w sytuacji kryzysowej, jest oczywiście przytaczana już ustawa o zarządzaniu kryzysowym. Reguluje ona zasady, na jakich siły zbrojne wspierają państwo, gdy wprowadzenie stanu nadzwyczajnego nie jest uzasadnione ${ }^{34}$.

Zgodnie z ustawą pododdziały lub oddziały sił zbrojnych mogą zostać skierowane do wykonywania zadań z dziedziny zarządzania kryzysowego. Jest tak, gdy nie jest możliwe użycie innych sił i środków lub też ich użycie może być niewystarczające. Siły zbrojne są przekazywane na wniosek i do dyspozycji wojewody przez Ministra Obrony Narodowej. Mogą one stanowić pomoc i wsparcie w realizacji takich zadań, jak izolacja miejsca wystąpienia zagrożenia, ewakuacja

32 http://www.mon.gov.pl/sily-zbrojne/ (dostęp: 24.03.2017).

33 K. Graczyk, G. Nakielski, T. Tabaczniuk, Elementy zarzadzania kryzysowego w administracji publicznej, Zielona Góra 2015, s. 175.

34 W. Smolski, Sity Zbrojne Rzeczypospolitej Polskiej w zarzadzaniu kryzysowym, [w:] Zarządzanie kryzysowe. Wybrane problemy, red. G. Kędzierska, A. Pepłoński, Z. Siemaka, Białystok 2013, s. 452-453. 
ludności i mienia, prowadzenie prac poszukiwawczo-ratowniczych, współudział w monitorowaniu zagrożeń, udzielanie pomocy medycznej, usuwanie promieniotwórczych skażeń, usuwanie niebezpiecznych materiałów i ich unieszkodliwianie, a także prowadzenie innego rodzaju prac, które wymagają użycia specjalistycznego sprzętu. Ważne jednak, by użycie sił zbrojnych w sytuacji kryzysowej nie zakłóciło realizacji przez nie zadań konstytucyjnych oraz wynikających z ratyfikowanych umów międzynarodowych ${ }^{35}$.

\section{WSPÓŁDZIAŁANIE Z ORGANIZACJAMI POZARZĄDOWYMI}

Przez organizacje pozarządowe rozumiemy organizacje, których działalność ma charakter społeczny, niedochodowy (non profit), niezależny od struktur państwa i samorządu terytorialnego. Mogą one działać dzięki konstytucyjnie zapewnionej wolności zrzeszania się ${ }^{36}$. Jednym z najważniejszych aktów, za pomocą którego realizowana jest ta konstytucyjna wolność, jest Prawo o stowarzyszeniach. Ustawodawca uznał w nim stowarzyszenie za dobrowolne, samorządne oraz trwałe zrzeszenie o niezarobkowych celach. Swoją działalność opiera ono na pracy społecznej członków, może jednak dodatkowo zatrudniać pracowników do prowadzenia określonych spraw ${ }^{37}$. Do organizacji pozarządowych zalicza się też fundacje, których podstawą funkcjonowania jest ustawa o fundacjach. Ich zadaniem jest realizowanie celów społecznie lub też gospodarczo użytecznych. Wśród celów tych ustawa wskazuje między innymi na ochronę zdrowia, opiekę i pomoc społeczną oraz ochronę środowiska ${ }^{38}$. Aktem prawnym istotnym dla funkcjonowania organizacji pozarządowych jest ustawa o działalności pożytku publicznego i o wolontariacie. Zgodnie z jej treścią działalnością pożytku publicznego jest działalność, która ma społecznie użyteczny charakter oraz prowadzona jest przez organizacje pozarządowe w sferze zadań publicznych. Katalog zadań, w których organizacje pozarządowe mogą wspierać państwo, został wskazany w ustawie i odnosi się do sfer związanych między innymi z porządkiem i bezpieczeństwem publicznym, obronnością państwa oraz działalnością sił zbrojnych RP, ratownictwem i ochroną ludności, pomocą ofiarom katastrof, klęsk żywiołowych, konfliktów zbrojnych i wojen. Organizacje pozarządowe mogą więc być wsparciem państwa w wykonywaniu wielu zadań ściśle związanych z zarządzaniem kryzysowym ${ }^{39}$.

35 Zob. art. 25 ustawy o zarządzaniu kryzysowym.

${ }^{36}$ Konstytucja Rzeczypospolitej Polskiej w art. 12 stanowi: „Rzeczpospolita Polska zapewnia wolność tworzenia i działania związków zawodowych, organizacji społeczno-zawodowych rolników, stowarzyszeń, ruchów obywatelskich, innych dobrowolnych zrzeszeń oraz fundacji”.

37 Zob. art. 2 ustawy z dnia 7 kwietnia 1989 roku — Prawo o stowarzyszeniach (Dz.U. z 2017 r. poz. 210).

38 Zob. art. 1 ustawy z dnia 6 kwietnia 1984 roku o fundacjach (Dz.U. z 2016 r. poz. 40).

39 Zob. art. 4 ustawy z dnia 24 kwietnia 2003 roku o działalności pożytku publicznego i o wolontariacie (Dz.U. z 2016 r. poz. 1817, z późn. zm.). 
Organizacje pozarządowe, które mogą być użyteczne w systemie zarządzania kryzysowego, podzielić możemy na cztery kategorie: ochotnicze straże pożarne (dalej: OSP), społeczne organizacje ratownicze, organizacje społeczno-wychowawcze oraz takie organizacje, które są w posiadaniu specjalnych zasobów.

OSP oraz tworzony przez nie Związek Ochotniczych Straży Pożarnych to jednostki ochrony przeciwpożarowej działające na podstawie wspomnianej już ustawy Prawo o stowarzyszeniach. Dodatkowe uprawnienia przyznaje im jednak ustawa o ochronie przeciwpożarowej. Zgodnie z jej postanowieniami OSP to umundurowana jednostka, która wyposażona jest w specjalistyczny sprzęt służący do walki z pożarami, klęskami żywiołowymi oraz innymi miejscowymi zagrożeniami. W akcjach ratowniczych mogą brać bezpośredni udział ci członkowie, którzy ukończyli 18 lat, a nie przekroczyli 65. Dodatkowo muszą mieć aktualne badania lekarskie oraz odbyć wcześniej szkolenie pożarnicze ${ }^{40}$. OSP wspierają administrację publiczną $\mathrm{w}$ fazie reagowania procesu zarządzania kryzysowego. Ich zadaniem jest wsparcie pozostałych służb, inspekcji, straży, a także wszelkich innych podmiotów, jakie niosą pomoc bezpośrednią ofiarom zdarzenia.

Zgodnie z ustawą o Państwowym Ratownictwie Medycznym za społeczne organizacje ratownicze możemy uznać te organizacje, których zadaniem ustawowym lub statutowym jest niesienie pomocy osobom znajdującym się w stanie nagłego zagrożenia życia ${ }^{41}$. Do organizacji tych zaliczyć możemy Wodne Ochotnicze Pogotowie Ratunkowe, Górskie Ochotnicze Pogotowie Ratunkowe, a także Tatrzańskie Ochotnicze Pogotowie Ratunkowe ${ }^{42}$. Wsparcie z ich strony w sytuacjach kryzysowych polegać może na udostępnieniu własnego potencjału kadrowego, sprzętowego oraz lokalowego. Przykładem społecznej organizacji ratowniczej może być również Polski Czerwony Krzyż, który prowadzi pomoc humanitarną, edukację w zakresie pierwszej pomocy oraz ma grupy ratownictwa ${ }^{43}$.

Organizacjami społeczno-wychowawczymi, których potencjał może zostać wykorzystany w zarządzaniu kryzysowym, jest ruch harcerski (przede wszystkim Związek Harcerstwa Polskiego) i ruch strzelecki (Związek Strzelecki „Strzelec” — Organizacja Społeczno-Wychowawcza, Związek Strzelecki, Związek Strzelecki „Strzelec” oraz Związek Strzelecki Rzeczypospolitej). Ich zadaniem jest prowadzenie działalności o charakterze wychowawczym i edukacyjnym, nakierowanej na dzieci i młodzież. Jedną z cennych umiejętności, na której zdobywanie te organizacje

40 Zob. art. 19 ustawy z dnia 24 sierpnia 1991 roku o ochronie przeciwpożarowej (Dz.U. z 2016 r. poz. 191 z późn. zm.).

${ }^{41}$ Zob. art. 15 ust. 2 ustawy z dnia 8 września 2006 roku o Państwowym Ratownictwie Medycznym (Dz.U. z 2016 r. poz. 1868 z późn. zm.).

42 Dodatkowe uprawnienia przydają im ustawa z dnia 18 sierpnia 2011 roku o bezpieczeństwie osób przebywających na obszarach wodnych (Dz.U. z 2016 r. poz. 656) oraz ustawa z dnia 18 sierpnia 2011 roku o bezpieczeństwie i ratownictwie w górach i na zorganizowanych terenach narciarskich (Dz.U. Nr 208, poz. 1241 z późn. zm.).

43 A. Morawski, Rola organizacji pozarzadowych w procesie zarządzania kryzysowego, „e-Politikon” 2013, nr 6, s. 195-196. 
są nastawione, jest udzielanie pierwszej pomocy przedmedycznej. Potencjał organizacji społeczno-wychowawczych w procesie zarządzania kryzysowego szczególnie istotny jest w fazie zapobiegania. Organizacje te przede wszystkim szkolą swoich członków, mogą też wspierać szkoły przez udział w nauczaniu przedmiotu edukacja dla bezpieczeństwa (na przykład pomoc w organizowaniu spotkań ze specjalistami w danej dziedzinie) oraz organizowanie wszelkiego rodzaju kursów, jak pierwsza pomoc $^{44}$.

Ostatnią grupą organizacji pozarządowych, które wspierają administrację w sytuacji kryzysowej, są organizacje dysponujące wyjątkowymi zasobami. Zasobami tymi mogą być zarówno sprzęt, lokal, jak i przeszkolone kadry. Organizacje te będą szczególnie pomocne, gdy organy władzy publicznej nie dysponują wymaganymi zasobami w ogóle lub też dysponują w niewielkim zakresie. Za przykład organizacji dysponującej wyjątkowymi zasobami posłużyć mogą aerokluby czy też kluby krótkofalarskie. Ich udział szczególnie istotny będzie w fazie reagowania ${ }^{45}$.

\section{PODSUMOWANIE}

Z sytuacją kryzysową mamy do czynienia, kiedy ludności, środowisku lub mieniu grozi niebezpieczeństwo, niebędące jednak wystarczającą przyczyną do wprowadzenia konstytucyjnego stanu nadzwyczajnego. Mieści się ono zatem w granicach normalnego funkcjonowania państwa. System zarządzania kryzysowego, który ma na celu zapobieganie sytuacjom kryzysowym oraz reagowanie i usuwanie skutków w przypadku ich wystąpienia, jest systemem zintegrowanym, wieloszczeblowym. Ustawa o zarządzaniu kryzysowym przypisuje kompetencje i obowiązki w tym zakresie organom zarówno państwowym, jak i samorządowym. Nie zawsze jednak siły i środki posiadane przez administrację publiczną są wystarczające. W takim wypadku korzysta ona ze wsparcia ze strony otoczenia. Na potrzeby niniejszej pracy przedstawiono zarys współpracy organów administracyjnych w sytuacjach kryzysowych z siłami zbrojnymi RP oraz organizacjami pozarządowymi.

\section{THE SPECIFICS OF THE RELATIONSHIP OF PUBLIC ADMINISTRATIONS WITH THE ENVIRONMENT IN CRISIS SITUATIONS}

Summary

We're dealing with a crisis situation in case of serious threat to life and property. This situation requires some special methods, but don't give basis to initiate one of the constitutional extraordinary

44 Ibidem, s. 197-198.

45 Ibidem, s. 198. 
measures. Law on crisis management contains tasks which belongs to organs of territorial self-government and organs of state administration. System of crisis management consists of organs of crisis management, subsidiary organs and crisis management centers. In crisis situations organs of public administration can also cooperate with the environment. The aim of this article is to analyze situations when organs of public administration are supported by The Armed Forces of the Republic of Poland and non-governmental organizations with their personnel, equipment and information.

Keywords: crisis situations, crisis management

\section{BIBLIOGRAFIA}

Akademia Obrony Narodowej, Słownik terminów z zakresu bezpieczeństwa narodowego, Warszawa 2008.

Bezpieczeństwo wewnętrzne $w$ działaniach terenowej administracji publicznej, red. A. Chajbowicz, T. Kocowski, Wrocław 2009.

Brzeziński M., Sytuacja kryzysowa w rozumieniu ustawy z dnia 26 kwietnia 2007 r. o zarzadzaniu kryzysowym - analiza pojęcia, „e-Politikon” 2013, nr 6.

Falecki J., Dylematy zarzadzania kryzysowego w Rzeczypospolitej Polskiej, Sosnowiec 2016.

Graczyk K., Nakielski G., Tabaczniuk T., Elementy zarządzania kryzysowego w administracji publicznej, Zielona Góra 2015.

Korczak J., Współdziałanie organów administracji rządowej $i$ samorządowej w stanach nadzwyczajnych, [w:] Powszechna ochrona ludności w stanach nadzwyczajnych w zadaniach terenowej administracji publicznej, red. M. Błażewski, T. Kocowski, M. Raduła, Wrocław 2016.

Leszczyński T.Z., Kluczowe zadania administracji samorzadowej w zarządzaniu kryzysowym. Bezpieczeństwo i zarzadzanie kryzysowe, „Przedsiębiorczość i Zarządzanie” 10, 2009.

Morawski A., Rola organizacji pozarzadowych w procesie zarzadzania kryzysowego, „e-Politikon” 2013, nr 6.

Ostapski A., Zadania gminy w zakresie bezpieczeństwa, [w:] Bezpieczeństwo wewnętrzne w działaniach terenowej administracji publicznej, red. A. Chajbowicz, T. Kocowski, Wrocław 2009.

Prawo administracyjne, red. M. Wierzbowski, Warszawa 2017.

Prawo administracyjne. Pojęcia, instytucje, zasady w teorii i orzecznictwie, red. M. Stahl, Warszawa 2016.

Smolski W., Sity Zbrojne Rzeczypospolitej Polskiej w zarządzaniu kryzysowym, [w:] Zarządzanie kryzysowe. Wybrane problemy, red. G. Kędzierska, A. Pepłoński, Z. Siemak, Białystok 2013.

Walczak W., Zarządzanie kryzysowe — rola i zadania organów administracji państwowej, „Przedsiębiorczość i Zarządzanie" 10, 2009, z. 8.

Zarządzanie kryzysowe. Wybrane problemy, red. G. Kędzierska, A. Pepłoński, Z. Siemak, Białystok 2013.

Serwis internetowy Ministerstwa Obrony Narodowej, http://www.mon.gov.pl/sily-zbrojne/.

Serwis internetowy Rządowego Centrum Bezpieczeństwa, http://rcb.gov.pl/o-rcb/.

Słownik języka polskiego, https://sjp.pwn.pl/. 